\title{
Natural thickener in raw and cooked fish-derived: microbiological, physicochemical and sensorial acceptance
}

\author{
Espessante natural em derivados de pescado crus e cozidos: análises \\ microbiológicas, físico-químicas e aceitação sensorial
}

\section{Monique de Oliveira MAIA ${ }^{1}$; Marlene Nunes DAMACENO ${ }^{2}$; Renata Chastinet BRAGA ${ }^{3}$; Daniele Maria Alves Teixeira SÁ ${ }^{3}$}

\begin{abstract}
${ }^{1}$ Autor para correspondência. Mestranda em Tecnologia de Alimentos; Instituto Federal de Ciência e Tecnologia do Ceará - IFCE, Departamento de Pós Graduação em Tecnologia de Alimentos. Rua Estevão Remígio, 1145, Centro, 62930-000, Limoeiro do Norte, Ceara, Brasil.moniquemaia_@hotmail.com

2 Doutora em Alimentos e Professora; Instituto Federal de Ciência e Tecnologia do Ceará - IFCE, marlene@ifce.edu.br

${ }^{3}$ Doutora em Bioquímica e Professora; Instituto Federal de Ciência e Tecnologia do Ceará - IFCE, rchastinet@gmail.com; daneile.teixeira@gmail.com
\end{abstract}

Recebido em: 10-08-2014; Aceito em: 09-03-2015

\begin{abstract}
The development of fish derived products is different from fishery itself, and contributes to the local economy. Products such as fish burger and nuggets, made of fish as raw material, have been in the spotlight of the market in recent decades due to its nutritional properties and the increase in fish deriving activity. For some decades, the functional properties of polysaccharide gums have been studied in food industries. One of its main functions is the increase of viscosity, working as a thickener in aqueous solutions. This research aims to study the use of galactomannan from the seeds of Caesalpinia pulcherrima, commonly known as "flamboianzinho" in fish derived products prepared with the specie Oreochromis niloticus, known as Nile tilapia. Microbiological, physicochemical and sensory tests were conducted to evaluate the product and its acceptance and purchase intent of consumers. The results show that the three formulations of nuggets and hamburgers prepared with tilapia using Caesalpinia pulcherrima seeds as the thickener are within the microbiological standards required by Brazilian legislation. The physicochemical composition of the products was not affected by the addition of the gum and the products were well accepted as the appearance, odor, flavor, texture and global aspect, which obtained scores notes within the acceptance zone in all analyzed aspects. Most panelists declared that they would certainly buy or possibly buy the nuggets and hamburger prepared with tilapia, being, therefore, a good way of utilization of this species of fish and the Caesalpinia pulcherrima as thickeners in this type of product.
\end{abstract}

Additional keywords: fish burger; galactomannan; nuggets; sensorial analysis.

\begin{abstract}
Resumo
A produção de derivados de pescado é uma atividade diferenciada ao da pesca propriamente dita e contribui para a economia local. Produtos como o fish burger e nuggets produzidos com o pescado como matéria-prima têm ganhado enfoque no mercado, nas últimas décadas, pelo crescimento da atividade e por suas propriedades nutricionais. Há algumas décadas, vêm-se estudando as propriedades funcionais das gomas de polissacarídeo nas indústrias de alimentos. Uma de suas principais funções é no aumento da viscosidade, agindo como espessante em soluções aquosas. Este estudo tem como objetivo o uso de galactomanana das sementes de Caesalpinia pulcherrima, conhecida popularmente como "flamboianzinho", em derivados de pescado preparados com a espécie Oreochromis niloticus, conhecida como Tilápia-do-Nilo. Testes microbiológicos, físico-químicos e sensoriais foram conduzidos para avaliar o produto, sua aceitação e a intenção de compra dos consumidores. Os resultados obtidos mostram que as três formulações de nuggets e de hambúrguer preparadas com a tilápia, utilizando como espessante as sementes de Caesalpinia pulcherrima, estão dentro dos padrões microbiológicos exigidos pela legislação brasileira. A composição físico-química dos produtos não foi afetada pela adição de goma, e os produtos foram bem aceitos quanto à aparência, odor, sabor, textura e aspecto global, tendo obtido notas dentro da zona de aceitação do produto em todos os aspectos analisados. A maioria dos provadores declarou que certamente comprariam e possivelmente comprariam os nuggets e o hambúrguer de tilápia, sendo, portanto, uma boa forma de utilização dessa espécie de pescado e das sementes de Caesalpinia pulcherrima como espessante neste tipo de produto.
\end{abstract}

Palavras-chave adicionais: análise sensorial; fish burger; galactomanana; nuggets. 


\section{Introduction}

In 2010, the global production of cultivated edible aquatic species was 59.9 millions of tons with Brazil producing 479.399 tons, being $82.2 \%$ from continental aquaculture (FAO, 2012; MPA, 2012). Seafood is an important part of healthy diet (Trondsen et al., 2003), due the presence of fatty acids from n-3 and $n-6$ series which are precursors of prostaglandins, thromboxanes and leukotrienes, that have important functions in the body (Moreira et al., 2001). Among the species of fish consumed in Brazil, there is the Nile tilapia which is a specie that easily adapts to brackish waters (Machado, 1984) and possesses low level of cholesterol (Vila-Nova et al., 2005).

Lately, the use of gums extracted from plant seeds (galactomannans) has been studied in several products of the food industry. Galactomannans are often used for human consumption. With their diverse physicochemical properties, they are a versatile material with many applications. In simple aqueous systems, they are not only effective viscosifiers and thickeners, but also excellent stiffeners and stabilizers of emulsions (Silveira \& Bresolin, 2011). Caesalpinia pulcherrima is widely distributed in tropical and sub-tropical regions like India, Myanmar, Vietnam, Sri Lanka, and Malay Peninsula (Thombre \& Gide, 2013). The properties of galactomannans extracted from seeds of Caesalpinia pulcherrima have being studied in several work (Cerqueira et al., 2009; Braga et al., 2011; Thombre \& Gide, 2013).

The sensory analysis, done through human senses, aims to check the acceptance of food products. Thus, the sensations are used to develop new products in researches and to evaluate the food quality by the interaction of the human organs with the food. Besides, the sensations also evaluate the acceptability of the consumers (Stone \& Sidel, 2004).

This research aims to study the use of galactomannan from the seeds of Caesalpinia pulcherrima in the preparation of fish derived products using the specie Oreochromis niloticus and to characterize the products as microbiological, physicochemical and sensorial analysis.

\section{Material and methods}

Two products were evaluated: fish burger and nuggets. Both prepared with a fish paste base named as surimi, obtained from the Nile tilapia fillet, which was made as described in the flowchart (Figure 1). The ingredients to prepare both products were: $1 \mathrm{~kg}$ of surimi; $2 \mathrm{~g}$ of dehydrated fried garlic; 20 $\mathrm{g}$ of refined salt; $3 \mathrm{~g}$ of flavor enhancer monosodium glutamate; $2 \mathrm{~g}$ of sugar; $2 \mathrm{~g}$ of pepper.

The galactomannan was obtained in the Chemical Laboratory, following methodology of Braga et al. (2011). Was added in three formulations for each product: F1: did not contain the gum

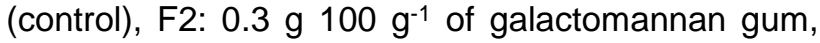

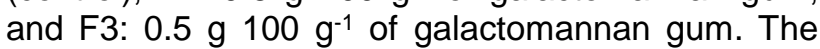
next step consisted in mixing the ingredients and placing the mass formed in forms for each product. Microbiological and physicochemical analyses were performed. After that, nuggets were precooked in the microwave and fish burger remained raw until the sensory test. For the sensorial tests, the nuggets were fried while fish burgers were baked on grill.

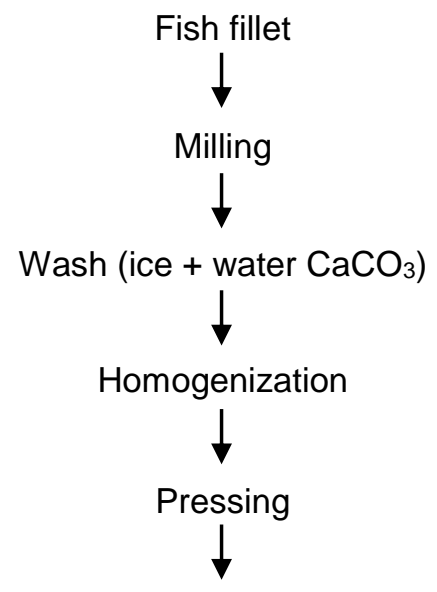

Fish paste<smiles>[3H][3H]</smiles>

Storage under refrigeration

Figure 1 - Flowchart for obtaining fish paste.

Analysis of coliforms at $45^{\circ} \mathrm{C}$ was performed according to the methodology recommended by the APHA (2001) to ensure the safety of panelists.

The samples were subjected to physicochemical analysis: Determination of $\mathrm{pH}$, water activity, moisture, ash, protein and lipids, according to the methods described by the Instituto Adolfo Lutz (2008). All tests were conducted in triplicate.

Each derived product, with its respective formulation, was analyzed with the acceptance test through a nine-scored hedonic scale, with scores varying from 1 (Extremely dislike) to 9 (Extremely like) (Dutcosky, 2011).

The purchase intention of consumers towards the products, based on the consumers' impression on the products, was evaluated through a purchase intention test of five aspects: appearance, smell, flavor, texture and global aspect. Then, the purchase intention test was applied to the nugget and the fish burger. The consumers had to choose one alternative: "Certainly buy," "possibly buy", "maybe buy / maybe not buy," "possibly not buy "and" certainly not buy".

The sensory study was performed with forty untrained panelists. Samples were presented in randomized blocks, each block was considered a tester. 
The analysis results were submitted to analysis of variance (ANOVA) and means were compared among themselves by Tukey Test at $5 \%$ probability.

\section{Results and discussions}

The test for coliforms at $45^{\circ} \mathrm{C}$ presented as a result MPN (Most Probable Number) equal to 15 or 102. According to Resolution of the Collegiate Direction (RDC) 12/2001 (BRASIL, 2001) which defines the criteria and microbiological standards for food, the product is considered within the microbiological standards of identity and quality which is $10^{3} \mathrm{MPN}$ for products based on chilled or frozen fish (hamburgers and similar). Therefore, the results of this research are satisfactory.

As to composition, Ogawa \& Maia (1999) state that the fish muscle may contain $60-85 \%$ of moisture, $20 \%$ of protein, $1-2 \%$ of ash, $0.3-1.0 \%$ of carbohydrate and $0.6-36 \%$ of lipids. Lipid shows greater variation, depending on the type of body muscle in the same species. In Table 1 are presented the obtained values of physicochemical analysis of tilapia nuggets made with natural thickener in formulations F1, F2 and F3.

Table $\left.1-{ }^{*}\right)$ Results obtained for the analysis of $\mathrm{pH}$, water activity, moisture, protein and lipid in nuggets formulated with natural thickener.

\begin{tabular}{ccccccc}
\hline Formulation & $\mathrm{pH}$ & ${ }^{(*)}$ Water Activity & Moisture $(\%)$ & Protein (\%) & Lipids (\%) & Ash (\%) \\
\hline F1 & $6.76 \mathrm{a}$ & $1.02 \mathrm{a}$ & $78.20 \mathrm{a}$ & $16.82 \mathrm{a}$ & $3.40 \mathrm{a}$ & $0.68 \mathrm{a}$ \\
F2 & $6.89 \mathrm{a}$ & $1.03 \mathrm{a}$ & $79.12 \mathrm{a}$ & $16.59 \mathrm{a}$ & $3.46 \mathrm{a}$ & $0.69 \mathrm{a}$ \\
F3 & $6.82 \mathrm{a}$ & $1.01 \mathrm{a}$ & $77.72 \mathrm{a}$ & $9.87 \mathrm{~b}$ & $3.76 \mathrm{a}$ & $1.28 \mathrm{a}$
\end{tabular}

${ }^{\left({ }^{\star}\right)}$ Averages with the same letter in the same column do not present statistically significant differences $(p>0.05)$; ${ }^{(*)}$ Water activity at $24.2^{\circ} \mathrm{C}$.

The $\mathrm{pH}$ values were similar for the three formulations, with values of $6.76,6.89$ and 6.82 for F1, F2 and F3, respectively. According to Ogawa \& Maia (1999) much of the fresh food, such as meat, fish and plant products, is slightly acidic (pH 5.0 to 6.5).

According to Bordignon et al. (2010), the moisture of tilapia croquettes made with mechanically separated meat was $79.05 \%$ and the croquettes made with shavings ' $\mathrm{V}$ ' was $81.27 \%$. The moisture content in the present study was 78.2 and 77.72 in formulations $F 1$ and $F 3$, respectively, and 79.12 in formulation F2. The processing methodology used may have influenced these results, since the washing step of the base folder (Figure 1), may be the cause of high moisture content and water activity (Table 1). According to Souza et al. (2010) in formulations of nuggets with concentrated shrimp "beef marine" and meat, moisture values were lower than the formulated product yielding 59.8 and $59.7 \%$, respectively. Another factor that may have contributed is the intrinsic characteristics of the fish and their own natural habitat.

Protein content ranged from 9.87 to $16.82 \%$, being similar to those found by Bordignon et al (2010), who obtained 15.11 and 15.34 in croquettes made with tilapia mechanically separated meat and meat trimmings, respectively. Pointing out that the gum polysaccharide does not negatively interfere on the physicochemical characteristics, neither the changes, what is observed is a thickening function regarding the malleability of mass, positively improving the modeling of nuggets in processing. The discrepancy in lipid value with the values found in this study is related to the base washes folder (Figure 1), in which fat globules are carried. According to Oetterer (2002) the underlying technology of the production of protein concentrates for fish process, is the concentration of its protein and remove fat fish through the extraction of lipids.

The physicochemical results found for fish burger are shown in Table 2.

Table $2-{ }^{(*)}$ Results obtained for the analysis of $\mathrm{pH}$, water activity, moisture, protein and lipids in fish burger made with natural thickener.

\begin{tabular}{clccccc}
\hline Formulation & $\mathrm{pH}$ & ${ }^{(*)}$ Water Activity & Moisture (\%) & Protein (\%) & Lipids (\%) & Ash (\%) \\
\hline F1 & $6.57 \mathrm{c}$ & $1.03 \mathrm{a}$ & $80.37 \mathrm{a}$ & $13.38 \mathrm{a}$ & $3.73 \mathrm{a}$ & $0.70 \mathrm{a}$ \\
F2 & $6.65 \mathrm{a}$ & $1.03 \mathrm{a}$ & $82.05 \mathrm{a}$ & $12.65 \mathrm{a}$ & $3.75 \mathrm{a}$ & $0.67 \mathrm{~b}$ \\
F3 & $6.60 \mathrm{~b}$ & $1.03 \mathrm{a}$ & $79.86 \mathrm{a}$ & $13.38 \mathrm{a}$ & $4.05 \mathrm{a}$ & $1.09 \mathrm{c}$ \\
\hline
\end{tabular}

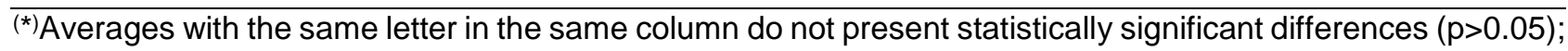
${ }^{(*)}$ Water activity at $28.0^{\circ} \mathrm{C}$.

Silva \& Fernandes (2010), in a study on preparation of fish burger with Corvina (Argyrosomus

regius), observed 6.55 for analysis of $\mathrm{pH}$, similar to the results found in this study, which ranged from 6.57 
to 6.65 (Table 2). The refereed authors also observed values of $68.11 \%$ and $1.54 \%$ for moisture and ash, respectively, being these values similar to those found in the present study, and protein of $22.75 \%$ which is higher than those observed in this study. The lipid content of $0.92 \%$ was lower than those found in this study and may be due to the type of fish used which was Corvina (lower lipid content than Tilapia).

The minimum and maximum values of moisture in four different formulations of fish burger prepared with mechanically separated meat of tilapia by Marengoni et al. (2009) were 71.05 and $76.86 \%$ being quite similar to those in the present study (Table 2). The referred authors also observed results ranging from 15.50 to $17.74 \%, 1.2$ to $2.44 \%$ and 1.73 to $10.28 \%$ of proteins, ash and ether extract, respectively. According to Ogawa \& Maia (1999) the physical and chemical composition of the edible portion of fish and shellfish varies between 60 and
$85 \%$ of moisture.

The acceptance of the nugget, concerning the evaluated criteria, is exposed in Table 3 . The smell, flavor and global aspect features did not show any significant difference $(p>0.05)$ between the samples. While the appearance and texture characteristics showed significant difference $(p<0.05)$, since the polysaccharide revealed high thickening potential. Oliveira et al. (2012), studying the acceptance of meat balls prepared with tilapia, did not observed difference in the appearance, flavor, smell, color and global acceptance among the different formulations.

To the smell and flavor attributes in the fish burger, there was no significant difference $(p>0.05)$, whereas the appearance, texture and global aspects showed difference in their values (Table 4).

Table $3-{ }^{(*)}$ Averages of the sensory characteristics in the acceptance test of the hedonic scale for the three tilapia nugget formulations.

\begin{tabular}{lccc}
\hline Characteristics & F1 & F2 & F3 \\
\hline Appearance & $7.77 \mathrm{a}$ & $7.57 \mathrm{~b}$ & $7.30 \mathrm{c}$ \\
Smell & $7.60 \mathrm{a}$ & $7.30 \mathrm{a}$ & $7.27 \mathrm{a}$ \\
Flavor & $7.67 \mathrm{a}$ & $7.42 \mathrm{a}$ & $7.17 \mathrm{a}$ \\
Texture & $7.12 \mathrm{a}$ & $7.82 \mathrm{a}$ & $7.42 \mathrm{a}$ \\
Global Aspect & $7.72 \mathrm{a}$ & $7.60 \mathrm{a}$ & $7.35 \mathrm{a}$ \\
\hline${ }^{*}$ Averages with the same letter in the same line do not present statistically significant differences $(\mathrm{p}>0.05)$.
\end{tabular}

Table $\left.4-{ }^{*}\right)$ Averages of the sensory characteristics in the acceptance test of the hedonic scale for the three tilapia fish burger formulations.

\begin{tabular}{lccc}
\hline Characteristics & F1 & F2 & F3 \\
\hline Appearance & $6.25 \mathrm{~b}$ & $6.77 \mathrm{~b}$ & $7.40 \mathrm{a}$ \\
Smell & $7.07 \mathrm{a}$ & $7.15 \mathrm{a}$ & $7.12 \mathrm{a}$ \\
Flavor & $7.02 \mathrm{a}$ & $7.17 \mathrm{a}$ & $7.22 \mathrm{a}$ \\
Texture & $5.70 \mathrm{~b}$ & $6.65 \mathrm{ab}$ & $6.70 \mathrm{a}$ \\
Global Aspect & $6.90 \mathrm{c}$ & $7.22 \mathrm{~b}$ & $7.37 \mathrm{a}$ \\
\hline${ }^{\star}$ Averages with the same letter in the same line do not present statistically significant difference $(\mathrm{p}>0.05)$.
\end{tabular}

Simões et al. (1998), studied fish burgers prepared with fish protein basis and added pork and chicken flavors. For each flavor, three formulations were made. Then, difference and acceptance tests were applied, being the latter analyzed through hedonic scale, which presented nine options varying from "Extremely dislike" to "Extremely like". The participants mentioned the consistency and texture as important factors in the product. In this research, the product showed significant difference $(p \leq 0.05)$ in formulation $\mathrm{F} 2$, more specifically in relation to texture. That confirms the consumer's thought about this aspect mentioned in Simões et al (1998) research.
The result of the nugget purchase intention test pointed satisfactory result, in which $57.5 \%$ of consumers said they would certainly buy the product; $27.5 \%$ would possibly buy it; $12.5 \%$ may or may not buy the nuggets; $0 \%$ would not possibly buy it and $2.5 \%$ would surely not buy. Souza et al. (2010), studying the physicochemical, sensorial characterization and development of formulated nuggets with concentrated fish protein - marine beef, obtained good product acceptance, with no significant difference between the tested formulations. The result was also satisfactory for fish burger, where $32.5 \%$ of the participants reported that will certainly buy the 
product; $45 \%$ will possibly buy; $20 \%$ may or not buy; $2.5 \%$ will not possibly buy and $0 \%$ will not certainly buy. The sensorial acceptance, the intention to purchase or the rejection of a product may be related to several factors. Among them, we can highlight the cultural habits and patterns, in addition to the individual perceptions, loyalty to certain brands, age, place of consumption, number and type of accompanying consumers at the time they acquire the product (Dasso, 1999). That was also shown by Noronha et al. (2005), in a study about the consumer's expectations and their effects in the sensorial evaluation and acceptance of food items.
These authors reported that the expectation is between the factors that influence in the perception of food products, which may be related to several individual reasons, which interact with physiological, behavioral and cognitive aspects.

Marengoni et al (2009) in their study about the microbiological, sensorial and centesimal characterization of tilapia fish burgers mechanically separated, observed inferior results to the ones obtained in the present research, with averages for the purchase intention standard, ranging from 3.86 to 3.98 , which point to results "maybe/maybe not buy" and "possibly buy" the product (Figure 2 ).

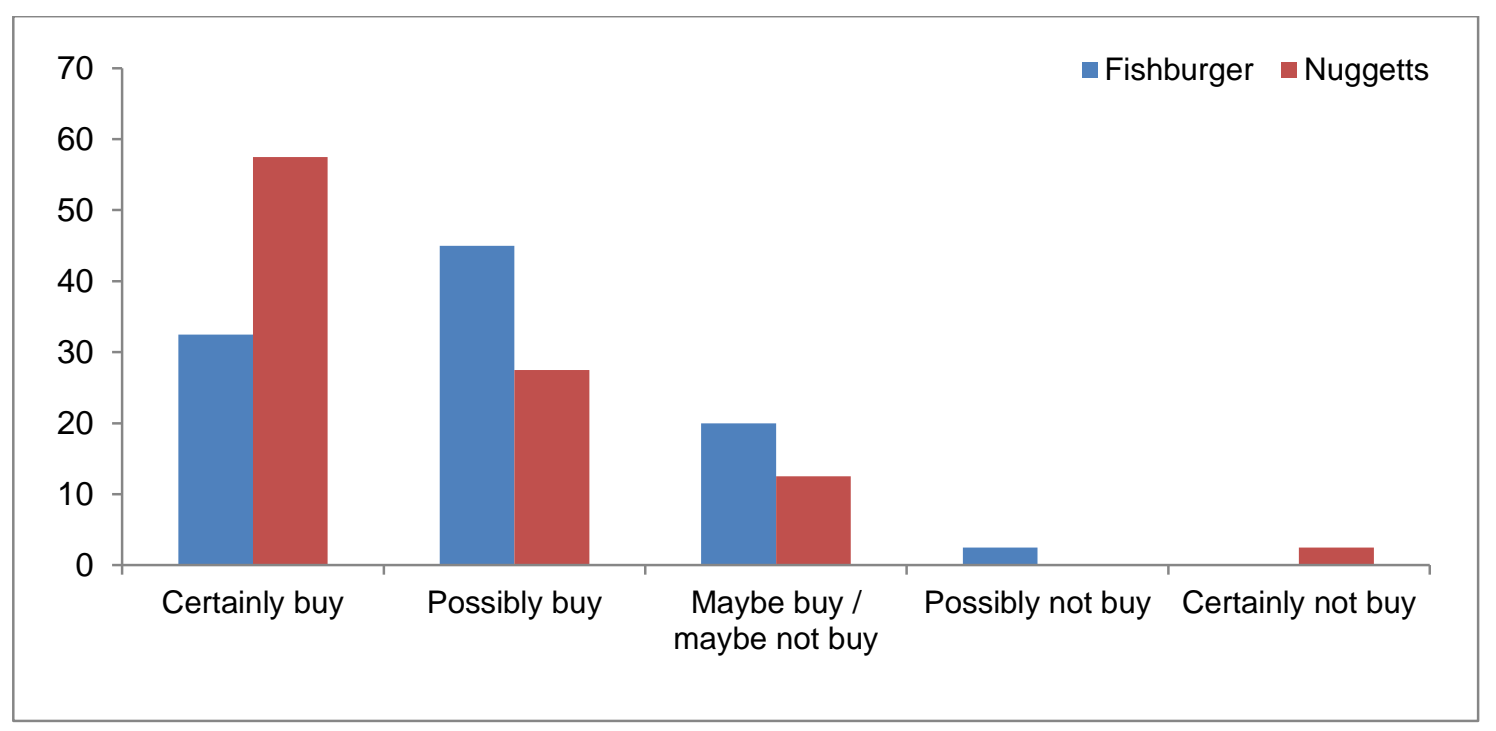

Figure 2 - Percentage of responses on the attitude of consumers to purchase fish derived products: fish burger and nuggets.

Sensory analysis is used as a tool for evaluating the sensory quality of foods by measuring and analyzing reactions in relation to their characteristics, which may be differentiated by human evaluation. In the fish meat we find several characteristics that influence the choice of purchasing a food concerning sensory quality and storage capacity. The chemical composition of a fish species has large variation, this will depend on the age of the animal, season, habitat, nutritional status and sexual maturation, body area and muscle type (light or dark) and even sex (Gonçalves, 2011).

\section{Conclusions}

According to the physicochemical analysis, it is concluded that tilapia nuggets and fish burger prepared with polysaccharide gum do not interfere in their chemical composition. For the sensory characteristics, the three formulations of nuggets and hamburgers prepared with tilapia using Caesalpinia pulcherrima seed as the thickener were well accepted by the panelists, which declared to have intention to buy these products.

\section{Acknowledgments}

The authors are grateful to Brazilian National Council for Scientific and Technological Development (CNPq), Brazilian Coordination of Improvement of Higher Level Personal (Capes) and Foundation Support Researcher of Ceará State (Funcap) for financial support.

\section{References}

APHA - American Public Health Association (2001). Compendium of Methods for the Microbiological Examination of Foods. 4 Ed. Washington: APHA, 2001. $676 \mathrm{p}$.

Bordignon AC, Souza BE, Bohnenberger L, Hilbig CC, Feiden A, Boscolo WR (2010) Elaboração de croquete de tilápia do Nilo (Oreochromis niloticus) a partir de CMS e aparas do corte em ' $V$ ' do filé e sua avaliação físico-química, microbiológica e sensorial. Acta Scientiarum. Animal Sciences 32(1):109-116. 
Braga RC, Teixeira-Sá DMA, Ribeiro AF, Miranda RL, Almeida LM, Horta ACG, Moreira RA (2011) Evaluation of Caesalpinia pulcherrima endospermic gum as affinity matrices for galactose-binding lectins interaction. Brazilian Archives of Biology and Technology 54(2):283-292.

BRASIL (2001) Ministério da Saúde. Secretaria da Vigilância Sanitária. Resolução da RDC n 12 de 02 de janeiro de 2001. Regulamento técnico sobre padrões microbiológicos em alimentos.

Cerqueira MA, Pinheiro AC, Souza BWS, Lima AMP, Ribeiro C, Miranda C, Teixeira JA, Moreira RA, Coimbra MA, Gonçalves MP, Vicente AA (2009) Extraction, purification and characterization of galactomannans from non-traditional sources. Carbohydrate Polymers 75(3):408-414.

Dasso I (1999) Qué pondemos en juego al degustar un alimento? La Alimentación Latinoamericana 33(229):34-36.

Dutcosky SD (2011) Análise sensorial de alimentos. $3^{\text {a }}$ ed. rev. ampl. Curitiba: Champagnat, 426p.

FAO - Food and Agriculture Organization of the United Nations (2012) Fisheries and Aquaculture Department. The state of world fisheries and aquaculture. FAO: Rome.

Gonçalves AA (2011) Tecnologia do pescado: ciência, tecnologia, inovação e legislação. São Paulo: Atheneu, 608p.

Instituto Adolfo Lutz (2008) Métodos físico-químicos para análise de alimentos. 1aㅡ edição digital. São Paulo: Instituto Adolfo Lutz.

Machado ZL (1984) Tecnologia de recursos pesqueiros: parâmetros, processos, produtos. Recife: SUDENE, 176p.

Marengoni NG, Pozza MSS, Braga GC, Lazzeri DB, Castilha LD, Bueno GW, Pasquetti TJ, Polese C (2009) Caracterização microbiológica, sensorial e centesimal de fishburgers de carne de tilápia mecanicamente separada. Revista Brasileira Saúde e Produção Animal 10(1):168-176.

Moreira AB, Visentainer JV, Souza NE, Matsushita M (2001) Fatty acids profile and cholesterol contents of three Brazilian Brycon Freshwater Fishes. Journal of Food Composition and Analysis 14:565-574.

MPA - Ministério da Pesca e Aquicultura (2012). Boletim Estatístico da Pesca e Aquicultura, Brasil 2010. MPA: Brasília, 101p.
Noronha RLF, Deliza R, Silva MAAP (2005) A expectativa do consumidor e seus efeitos na avaliação sensorial e aceitação de produtos alimentícios. Alimentos e Nutrição 16(3):299-308.

Oetterer M (2002) Proteínas do Pescado. Escola Superior de Agricultura "Luíz de Queiroz". São Paulo - SP. 65 p.

Ogawa M, Maia EL (1999) Manual de pesca: ciência e tecnologia do pescado. São Paulo: Varela. 430 p.

Oliveira MC, Cruz GRB, Almeida NM (2012) Características microbiológicas, físico-químicas e sensoriais de "Almôndegas" à base de polpa de tilápia (Oreochromis niloticus). UNOPAR Científica, Ciências Biológicas e da Saúde 14(1):37-44.

Silva SR, Fernandes ECS (2010) Aproveitamento da Corvina (Argyrosomus regius) para elaboração de fishburguer. Cadernos de Pesca 17(3):67-70.

Silveira JLM, Bresolin TMB (2011) Pharmaceutical use of galactomannans. Química Nova 34(2):292299.

Simões DRS, Pedroso MA, Ruiz WA, Almeida TL (1998) Hambúrgueres formulados com base protéica de pescado. Ciência e Tecnologia de Alimentos 18(4):410-413.

Souza JF, Bitencourt NN, Gomes CS, Oliveira JK, Santos RM, Reis IAO, Nunes ML, Narain N (2010) Desenvolvimento e caracterização físico-química e sensorial de nuggets formulados com concentrado protéico de pescado - marine beef. Scientia Plena 6(3):1- 4.

Stone H, Sidel JL (2004) Sensory evaluation practices. 3rd ed. Boston: Elsevier Academic Press, $377 p$.

Thombre NA, Gide PS (2013) Rheological characterization of galactomannans extracted from seeds of Caesalpinia pulcherrima. Carbohydrate Polymers 94(1):547-554.

Trondsen T, Scholderer J, Lund E, Eggen AE (2003) Perceived barriers to consumption of fish among Norwegian women. Appetite 41:301-314.

Vila-Nova CMVM, Godoy HT, Aldrigue ML (2005) Composição química, teor de colesterol e caracterização dos lipídios totais de tilápia (Oreochromis niloticus) e pargo (Lutjanus purpureus). Ciência e Tecnologia de Alimentos 25(3):430-436. 